\title{
Industry's Open Payments to Physicians in the United States: What Have We Learned?
}

\author{
Azza AbuDagga* \\ Health Services Researcher, Public Citizen, Health Research Group, 1600 20th Street NW, Washington, D.C. 20009, United States
}

*Corresponding author: Azza AbuDagga, Health Services Researcher, Public Citizen, Health Research Group, 1600 20th Street NW, Washington, D.C. 20009, United States, Tel: 202-588-7732, Fax: 202-588-7796; E-mail: aabudagga@citizen.org

Received: Jan 27, 2018; Accepted: Feb 26, 2018; Published: Feb 28, 2018

Copyright: (c) 2018 AbuDagga A. This is an open-access article distributed under the terms of the Creative Commons Attribution License, which permits unrestricted use, distribution, and reproduction in any medium, provided the original author and source are credited.

The Institute of Medicine considers a conflict of interest to exist "when an individual or institution has a secondary interest ... that creates a risk of undue influence on decisions or actions affecting a primary interest ... [such as] the conduct of objective and trustworthy medical research." [1]

Payments from pharmaceutical, medical device and biotechnology companies (the industry), made either directly to physicians or indirectly as funding for medical education and research, can create conflicts of interest by distorting physicians' prescribing practices in a manner that would favor the industry's commercial interests. For this reason, financial relationships between physicians and the industry have long troubled both patients and policymakers [2]. These concerns have led to calls for increased transparency [3] and regulation of these relationships [1].

As of 2013 in the U.S, the District of Columbia and five states Maine, Massachusetts, Minnesota, Vermont and West Virginia - have implemented programs that require pharmaceutical companies to disclose their spending on marketing to health care professionals [4]. At the federal level, the Physician Payments Sunshine Act, part of the Affordable Care Act of 2010, mandated the establishment of a transparency program, known as Open Payments, to publicly disclose all payments or other transfers of value by the industry to physicians or teaching hospitals that train resident physicians [5].

Under the Open Payments program, any of the following types of payments must be disclosed: charitable contributions, consulting fees, education, entertainment, gifts, grants, honoraria, food and beverages, ownership or investment interests (including stocks or stock options, partnership shares, company membership or bonds), research, royalty or license payments, speaker fees for continuing education programs, traveling and lodging, and space rental or facility fees (for teaching hospitals only).

In September 2014, the Centers for Medicare and Medicaid Services (CMS) in the U.S released the first batch of Open Payments data for payments made from August to December 2013 on a public website that identifies individual physicians or teaching hospitals that were reported to have received any of the aforementioned payments [6]. CMS updates the website with new data on a yearly basis and retains all data from previous years.

Below, I discuss the extent and effect of physician ties to the industry in light of some of the recent peer-reviewed publications that examined Open Payments data.

\section{Types and distribution of payments}

A recent study [7] that analyzed reported physician Open Payments data found that 449,864 physicians, representing approximately $48 \%$ of all physicians in the U.S., had received one or more industry payments in 2015.

The reported industry payments for physicians that year totaled $\$ 2.4$ billion. Of those payments, approximately three-quarters ( $\$ 1.8$ billion) were non-research or non-ownership-interest payments. The major components of these $\$ 1.8$ billion payments were royalty or license payments $(27 \%)$, fees for non-consulting services such as serving as faculty or speaking at an event $(27 \%)$, consulting fees $(17 \%)$, and payments for meals (12\%) and travel and lodging (9\%).

The study found that surgeons had an average per-physician total reported industry payment (excluding research and ownership interests) of $\$ 6,879$, compared with just $\$ 2,227$ in payments for primary care physicians. Overall, compared with primary care physicians, surgeons had $72 \%$ higher odds of receiving these types of payments.

Although less than $1 \%$ of U.S. physicians received ownership interest payments in 2015, these payments accounted for nearly a quarter ( $\$ 544$ million) of the $\$ 2.4$ billion of industry payments to physicians. In contrast, research payments made to individual physicians accounted for only 3\% (\$75 million) of the industry payments to physicians.

According to a CMS press release, the industry paid physicians or their immediate family members $\$ 1$ billion in ownership or investment interests and paid $\$ 3.9$ billion in research payments (including payments to teaching hospitals) in 2015 [8].

\section{Effect on physician prescribing}

Recent analyses of industry payments to physicians show that receipt of industry payments is associated with increased physician prescribing of brand-name drugs over lower-cost generic drugs that are equally safe and effective.

For example, a study of 2,444 physicians in the Massachusetts physicians payment database found that industry payments to physicians that reached or exceeded $\$ 2,000$ were associated with higher rates of prescribing brand-name statins [9], a frequently prescribed class of cholesterol-lowering medication with many lowcost generic alternatives with similar effectiveness. The study also found that, of the various types of industry payments made to physicians, those dedicated to educational training were associated with the highest rates of prescribing brand-name statins. 
A study that examined national Open Payments data from August to December 2013 found that physicians who attended a single industry meal promoting one of four specific brand-name drugs had significantly higher rates of prescribing those drug over equally effective alternatives from the same drug classes [10]. The majority of physicians in this study (95\%) received a single industry meal costing less than $\$ 20$ on average. The study also showed that both the receipt of additional meals and the receipt of meals that cost more than $\$ 20$ were associated with even higher rates of prescribing the four promoted brand-name drugs.

\section{Implications}

Additional evidence from Open Payments data is needed before broad conclusions can be drawn. However, the aforementioned findings illustrate that industry payments to physicians are widespread in the U.S. The evidence that both large and small payments influence physicians' prescribing of brand-name drugs lends support to the concern that these payments entrench major conflicts of interest in the U.S. health care system.

Although the creation of the Open Payments program is an important step in increasing public awareness about the potential financial conflicts of interest for individual physicians and teaching hospitals, it cannot curtail these conflicts of interest significantly on its own.

Public disclosure programs need to be coupled with reform efforts that remove conflicts of interest in health care by banning various forms of industry payments. For example, Stanford University Medical Center has prohibited its physicians and adjunct faculty from participating in speaking activities that involve industry products and from accepting industry meals or gifts, including pens and mugs $[11,12]$. This medical center also bars industry representatives from areas where patient treatment and physician education occur. The University of Michigan has banned the use of industry samples of prescription and non-prescription drugs in all of its clinics and hospitals and banned industry funding for continuing medical education [13].

The strict standards in the U.S. that prohibit publicly employed physicians from accepting industry gifts and funds[14] should be extended to physicians in the private sector. Policy makers need to create viable funding alternatives for professional medical education that are independent from industry funding. One such alternative is to increase taxes for the industry and to task a government agency with distributing these funds either directly or through an independent entity to support continuing medical education, professional conferences and other activities [14].

Ultimately, individual physicians must take a stance against industry influences because the obligations of physicians and those of the industry are incongruent: The obligation of physicians is to their patients, whereas the obligation of the industry is to shareholders.

As Dr. Jerome Hoffman, emeritus professor of medicine and emergency medicine at the University of California, Los Angeles, points out, physicians cannot put their patients' needs first if they "voluntarily create a conflict of interest for themselves by taking industry funding with one hand while writing prescriptions with the other. If a judge took money from a prosecuting attorney it would be considered a bribe ... The same should be true for doctors." [15]

\section{References}

1. Lo B, Field MJ, eds (2009) Conflict of Interest in Medical Research, Education, and Practice. Washington, DC: The National Academies Press.

2. Marshall DC, Jackson ME, Hattangadi-Gluth JA (2016) Disclosure of industry payments to physicians: An epidemiologic analysis of early data from the Open Payments Program. Mayo Clin Proc 91: 84-96.

3. Medicare Payment Advisory Commission (2009) Report to Congress: Medicare Payment Policy. Statement of Glenn M Hackbarth, JD, before the Subcommittee on Health, Committee on Ways and Means, US House of Representatives.

4. Gorlach I, Pham-Kanter G (2013) Brightening up: The effect of the Physician Payment Sunshine Act on existing regulation of pharmaceutical marketing. J Law Med Ethics 41: 315-322.

5. Centers for Medicare and Medicaid Services (nd) Fact sheet for physicians: Open payments (physician payments sunshine act).

6. Agrawal S, Brown D (2016) The Physician Payments Sunshine Act -- Two years of the Open Payments program. N Engl J Med 374: 906-909.

7. Tringale KR, Marshall D, Mackey TK, Connor M, Murphy JD, et al. (2017) Types and distribution of payments from industry to physicians in 2015. JAMA 317: 1774-1784.

8. Centers for Medicare and Medicaid Services (2016) CMS' Open Payments program posts 2015 financial data.

9. Yeh JS, Franklin JM, Avorn J, Landon J, Kesselheim AS (2016) Association of industry payments to physicians with the prescribing of brand-name statins in Massachusetts. JAMA Intern Med 176: 763-768.

10. DeJong C, Aguilar T, Tseng CW, Lin GA, Boscardin WJ, et al. (2016) Pharmaceutical industry-sponsored meals and physician prescribing patterns for Medicare beneficiaries. JAMA Intern Med 176: 1114-1122.

11. Stanford Medicine News Center (2010) Medical school extends ban on industry gifts, free samples to adjunct faculty.

12. Pollack A (2006) Stanford to ban drug makers' gifts to doctors, even pens.

13. University of Michigan (2014) U-M Health System industry interaction policies: Drug samples, drug reps, conflict of interest \& beyond.

14. Rodwin MA (2011) Reforming pharmaceutical industry-physician financial relationships: Lessons from the United States, France, and Japan. J Law Med Ethics 39: 662-670.

15. Perry S (2016) Sunshine Act has made only a small dent in physicianindustry transparency. 